\title{
Breast abscess due to Listeria sp: report of a rare case
}

\author{
KV Ramana \\ From 2nd International Science Symposium on HIV and Infectious Diseases (HIV SCIENCE 2014) \\ Chennai, India. 30 January - 1 February 2014
}

\section{Background}

Listeria sp. are facultative intracellular bacterial pathogens, which pose a potential public health problem related to consumption of contaminated food. Human listeriosis is clinically classified as perinatal listeriosis, neonatal listeriosis and adult listeriosis. Human infections caused by Listeria $s p$. present typically as meningitis. Other infections attributed to Listeria $s p$. include endocarditis, myocarditis, arteritis, pneumonia, pleuritis, cholecystitis, peritonitis, arthritis, osteomyelitis, sinusitis, otitis, conjunctivitis and ophthalmitis. We report a case of breast abscess in a young lactating patient.

\section{Case presentation}

A lactating 21 year-old lady presented to hospital with complaints of a lump in her right breast. On observation the size of the lump was $3 \mathrm{cmX} 1 \mathrm{~cm}$. Gram stain of the aspirated pus revealed short gram positive bacilli, and culture on blood agar grew small, round translucent beta hemolytic colonies with no growth on MacConkey agar. Conventional biochemical reactions showed that the isolated bacteria was motile at $25^{\circ} \mathrm{C}$ and non-motile at $37^{\circ} \mathrm{C}$ and cold enrichment at $40{ }^{\circ} \mathrm{C}, 10 \%$ salt $(\mathrm{NaCl})$ tolerance test and CAMP test were positive. Histopathological study of the tissue biopsy revealed extensive inflammation with no signs of granuloma. Empirical therapy including Amoxy clav $1.2 \mathrm{mg}$ TID and $400 \mathrm{mg}$ Ciprofloxacin TID was started. The patient responded well and had an uneventful recovery.

\section{Conclusion}

Human infections with Listeria sp. remain under reported owing to its unusual clinical presentation and complex physiological and biochemical characters.

Correspondence: ramana_20021@rediffmail.com

Department of Microbiology, Prathima Institute of Medical Sciences, Karimnagar, Andhrapradesh, India

(c) 2014 Ramana; licensee BioMed Central Ltd. This is an Open Access article distributed under the terms of the Creative Commons Attribution License (http://creativecommons.org/licenses/by/4.0), which permits unrestricted use, distribution, and reproduction in any medium, provided the original work is properly cited. The Creative Commons Public Domain Dedication waiver (http:// creativecommons.org/publicdomain/zero/1.0/) applies to the data made available in this article, unless otherwise stated.
Clinical microbiologists should be proactive in the laboratory identification of Listeria sp. as most isolates of Listeria are ignored as laboratory contaminants.

Published: 27 May 2014

doi:10.1186/1471-2334-14-S3-P20

Cite this article as: Ramana: Breast abscess due to Listeria sp: report of a rare case. BMC Infectious Diseases 2014 14(Suppl 3):P20.

Submit your next manuscript to BioMed Central and take full advantage of:

- Convenient online submission

- Thorough peer review

- No space constraints or color figure charges

- Immediate publication on acceptance

- Inclusion in PubMed, CAS, Scopus and Google Scholar

- Research which is freely available for redistribution

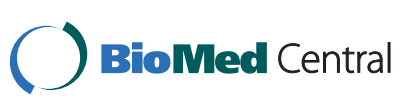

